\title{
Oxidation-Induced Structure Transformation: Thin-Film Synthesis and Interface Investigations of Barium Disilicide toward Potential Photovoltaic Applications
}

Yilei Tian, ${ }^{*}, \dagger$ Robin Vismara, ${ }^{\dagger}$ Steve van Doorene, ${ }^{\dagger}$ Pavol Šutta, ${ }^{\ddagger}$ L’ubomír Vančo, $^{\S}$ Marian Veselý, ${ }^{\S}$ Peter Vogrinčič, ${ }^{\S}$ Olindo Isabella, ${ }^{\dagger}$ and Miro Zeman

${ }^{\dagger}$ Photovoltaic Materials and Devices Group, Delft University of Technology, 2628 CD Delft, The Netherlands

${ }^{\ddagger}$ New Technologies Research Centre, University of West Bohemia, 30614 Plzeň, The Czech Republic

${ }^{\S}$ University Science Park Bratislava Centre, Slovak University of Technology in Bratislava, 81243 Bratislava, Slovak Republic

\section{Supporting Information}

\begin{abstract}
Barium disilicide $\left(\mathrm{BaSi}_{2}\right)$ has been regarded as a promising absorber material for high-efficiency thin-film solar cells. However, it has confronted issues related to material synthesis and quality control. Here, we fabricate $\mathrm{BaSi}_{2}$ thin films via an industrially applicable sputtering process and uncovered the mechanism of structure transformation. Polycrystalline $\mathrm{BaSi}_{2}$ thin films are obtained through the sputtering process followed by a postannealing treatment. The crystalline quality and phase composition of sputtered $\mathrm{BaSi}_{2}$ are characterized by Raman spectroscopy and X-ray diffraction (XRD). A higher annealing temperature can promote crystallization of $\mathrm{BaSi}_{2}$, but also causes an intensive surface oxidation and $\mathrm{BaSi} \mathrm{i}_{2} / \mathrm{SiO}_{2}$ interfacial diffusion. As a consequence, an inhomogeneous and layered structure of $\mathrm{BaSi}_{2}$ is revealed by Auger electron spectroscopy (AES) and transmission electron microscopy (TEM). The thick oxide layer in such an inhomogeneous structure hinders further both optical and electrical characterizations of sputtered $\mathrm{BaSi}_{2}$. The structural transformation process of sputtered $\mathrm{BaSi}_{2}$ films then is studied by the Raman depth-profiling method, and all of the above observations come to an oxidation-induced structure transformation mechanism. It interprets interfacial phenomena including surface oxidation and $\mathrm{BaSi}_{2} / \mathrm{SiO}_{2}$ interdiffusion, which lead to the inhomogeneous and layered structure of sputtered $\mathrm{BaSi}_{2}$. The mechanism can also be extended to epitaxial and evaporated $\mathrm{BaSi}_{2}$ films. In addition, a glimpse toward future developments in both material and device levels is presented. Such fundamental knowledge on structural transformations and complex interfacial activities is significant for further quality control and interface engineering on $\mathrm{BaSi}_{2}$ films toward high-efficiency solar cells.
\end{abstract}

KEYWORDS: barium disilicide, sputtering, annealing, structure transformation, interface, photovoltaic

\section{INTRODUCTION}

Sustainability, industrial ecology, and cost efficiency are regarded as key criteria guiding the development of the nextgeneration photovoltaic (PV) materials. ${ }^{1-4}$ Among a broad range of materials, the semiconducting barium disilicide $\left(\mathrm{BaSi}_{2}\right)$ has gained a renewed interest as a promising lightabsorbing material toward high-performance thin-film PV devices. ${ }^{5,6}$ The semiconducting $\mathrm{BaSi}_{2}$ is orthorhombic and can be ionically described as $2 \mathrm{Ba}^{2+}\left[\mathrm{Si}_{4}\right]^{4-}$, in which the $\mathrm{Si}$ atom is covalently bonded with three neighboring $\mathrm{Si}$ atoms and forms the characteristic unit tetrahedron $\left[\mathrm{Si}_{4}\right]^{4-7,8}$ The orthorhombic $\mathrm{BaSi}_{2}$ is stable in the ambient condition, ${ }^{9}$ exhibits an unintentionally n-type conductivity, ${ }^{10}$ and possesses a suitable band gap $\left(E_{\mathrm{g}}=\sim 1.3 \mathrm{eV}\right)$ for solar energy conversion. ${ }^{11-14}$ In addition, its great potential also stems from attractive optical and electrical properties, i.e., a high light absorption coefficient $(\alpha)$ reaching $10^{5} \mathrm{~cm}^{-1}$ for photon energy $h v>1.5 \mathrm{eV},{ }^{15,16}$ a long minority carrier lifetime $\tau$ $(\sim 10-27 \mu \mathrm{s}),{ }^{17-19}$ and essentially elemental abundance and nontoxicity. Theoretically, the attainable conversion efficiency $(\eta)$ of $\mathrm{BaSi}_{2}$ homojunction solar cells is up to $25 \% .^{5}$ Despite the huge promise that $\mathrm{BaSi}_{2}$ holds, the material is confronted with potential technological and scientific issues related to the material synthesis and quality control, which hinder further deployments of the material to cost-effective PV devices.

Low-cost synthesis routes of $\mathrm{BaSi}_{2}$ come to the forefront. In fact, high-quality $\mathrm{BaSi}_{2}$ films, which achieve an efficient solar cell device, have only been accomplished by the molecular beam epitaxy (MBE) technique. ${ }^{20,21}$ The distinct atomic-level film control advantage allows $\mathrm{MBE}$ a pioneering position in the high-quality material development. However, such an advantage always involves prohibitively expensive processes and the consequently high manufacturing cost, inhibiting the further practical applications. To this end, great efforts have been put

Received: March 26, 2018

Accepted: June 6, 2018

Published: June 6, 2018 

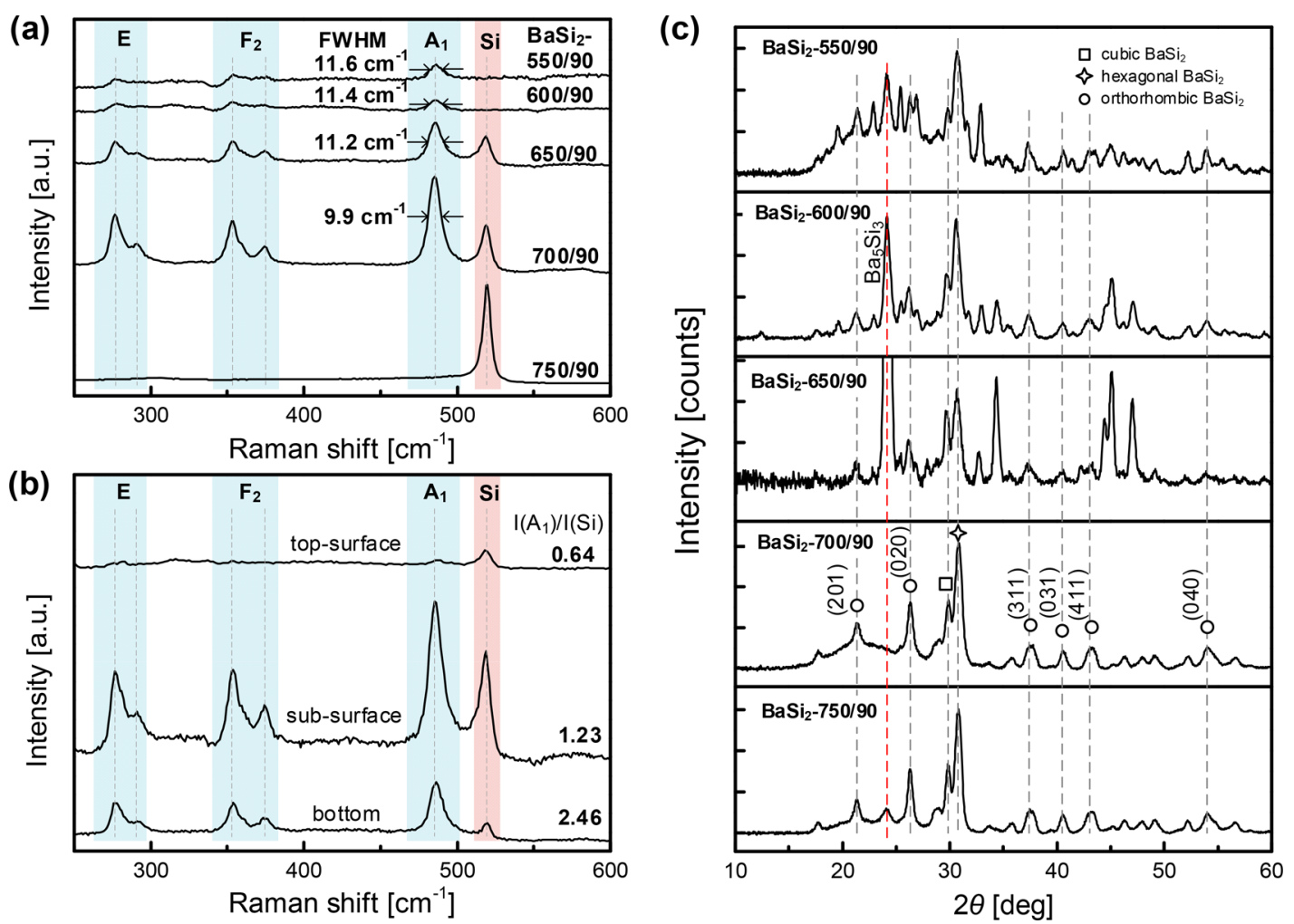

Figure 1. (a) Raman spectra of annealed $\mathrm{BaSi}_{2}$ (collected from the film side). (b) Raman depth profile of the sample $\mathrm{BaSi2}-650 / 90$. (c) XRD patterns of annealed $\mathrm{BaSi}_{2}$ films. All samples here are deposited on fused silica substrates.

into industrially applicable and commercially realistic processes for high-quality $\mathrm{BaSi}_{2}$ fabrications. In addition to the chemical vapor deposition (CVD) technique, ${ }^{22}$ more attention is focused on alternative low-cost physical vapor deposition (PVD) approaches, such as thermal evaporation and sputtering. ${ }^{14,23-26} \mathrm{BaSi}_{2}$ thin films on various substrates with a high deposition rate up to $840 \mathrm{~nm} / \mathrm{min}$ have been achieved via the thermal evaporation technique, presenting comparable quality to epitaxial films. ${ }^{14,25,27,28}$ Nevertheless, evaporationsource-related issues, including equilibrium vapor pressure difference and possible reactions with tungsten boat, increase difficulties in stoichiometry and further quality control of evaporated $\mathrm{BaSi}_{2}$. ${ }^{6}$ In this regard, the sputtering technique, another feasible option for thin-film fabrications, is taken into consideration. In addition to the high deposition rate and elimination of ultrahigh vacuum (UHV) equipment, the sputtering process exhibits an excellent stoichiometry control for compound material depositions. However, limited knowledge on sputtered $\mathrm{BaSi}_{2}$ films currently cannot support the further advancement from the material to practical PV devices. ${ }^{23,24,29,30}$ Fundamental research on synthesis and characterizations of sputtered $\mathrm{BaSi}_{2}$ films still remain needed to be carried out.

The other crucial issue is the material quality control of $\mathrm{BaSi}_{2}$ (especially at interfacial regions). The reactivity with oxygen and moisture does add difficulties to quality control at the air/ $\mathrm{BaSi}_{2}$ interface. ${ }^{6,31-33}$ The formed oxide layer consequently hinders the minority carrier (hole) transport with a barrier height of $3.9 \mathrm{eV} .^{33}$ The involved hightemperature conditions (Table S1) can further aggravate air/ $\mathrm{BaSi}_{2}$ interfacial oxidation. In addition to the air/ $\mathrm{BaSi}_{2}$ interface, the $\mathrm{BaSi}_{2} /$ solid (substrate) interface also experiences the atomic interdiffusion. Such interdiffusion alters the stoichiometry, results in defective phases, and then degrades the film quality. ${ }^{10,34}$ In fact, those interfacial phenomena both at air/ $\mathrm{BaSi}_{2}$ and at $\mathrm{BaSi}_{2} /$ substrate interfaces increase difficulties on material quality control. Even though some approaches to avoiding deleterious interfacial activities have been put forward ${ }^{19,20,35}$ the concealed mechanisms of these interactions are still not well-documented, especially for the sputtering case. A better understanding of those interfacial activities is a key goal that helps in developing qualityoptimization strategies $^{31,36}$ and designing solar cell architectures. $^{37,38}$

Indeed, here we present a $\mathrm{BaSi}_{2}$ thin-film synthesis route via an industrially applicable sputtering technique and reveal the structure transformation mechanism of $\mathrm{BaSi}_{2}$ in a hightemperature process. Polycrystalline $\mathrm{BaSi}_{2}$ thin films are obtained through the radio frequency (RF) sputtering process with a postannealing treatment. Higher annealing temperatures can enhance the crystallization of $\mathrm{BaSi}_{2}$, but also induced an inhomogeneous and layered structure. Such a structure hinders further characterizations and applications of sputtered $\mathrm{BaSi}_{2}$. Toward this, an oxidation-induced structure transformation mechanism is proposed on the basis of structural and interfacial observations and thermodynamic calculations. This knowledge regarding interfacial interactions and the structural transformation of $\mathrm{BaSi}_{2}$ films serves as the foundation for future research on quality-control and interface-engineering strategies of $\mathrm{BaSi}_{2}$ films toward solar cell applications.

\section{RESULTS AND DISCUSSION}

Synthesis and Characterizations of Sputtered $\mathrm{BaSi}_{2}$ Thin Films. The sputtered $\mathrm{BaSi}_{2}$ films on $10 \times 10 \mathrm{~cm}^{2}$ alkalifree glass presents a uniform thickness distribution with a target-substrate distance $d_{\mathrm{t}-\mathrm{s}}=135 \mathrm{~mm}$ (section S2, 

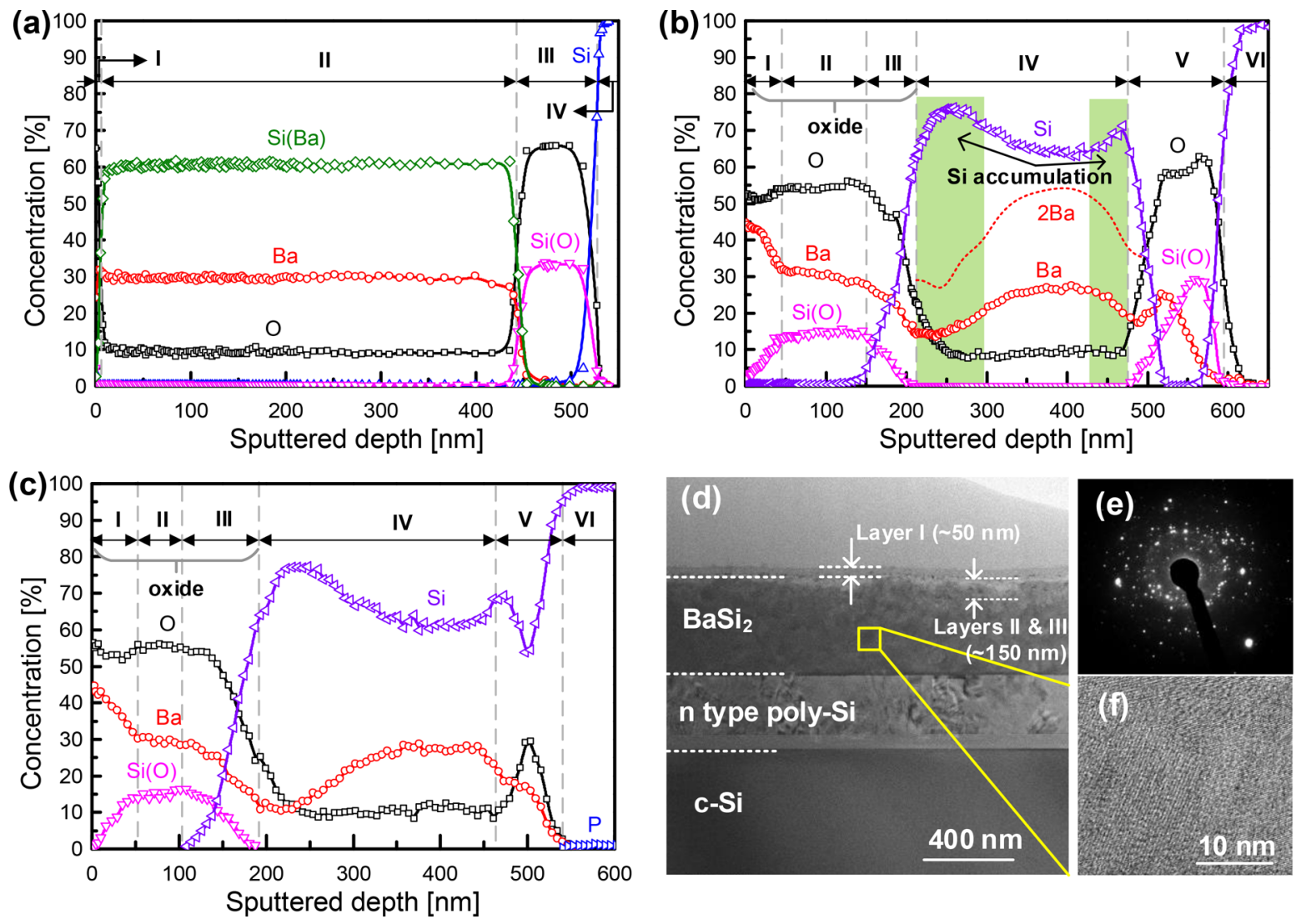

Figure 2. AES elemental concentration depth profiles of (a) $\left(\mathrm{BaSi}_{2}-\mathrm{RT} / 0\right) / \mathrm{SiO}_{2} / c-\mathrm{Si}$, (b) $\left(\mathrm{BaSi}_{2}-650 / 90\right) / \mathrm{SiO}_{2} / c-\mathrm{Si}$, and $(\mathrm{c})\left(\mathrm{BaSi}_{2}-650 / 90\right) / \mathrm{n}$ type poly-Si/c-Si. Si atoms bonded with $\mathrm{Ba}$ or $\mathrm{O}$ are marked as $\mathrm{Si}(\mathrm{Ba})$ and $\mathrm{Si}(\mathrm{O})$, respectively. It is hard to distinguish the metallic $\mathrm{Si}$ from that bonded with $\mathrm{Ba}$ in part b. (d) TEM cross-section image, (e) ED pattern, and (f) HR-TEM image of the $\left(\mathrm{BaSi}_{2}-650 / 90\right) / \mathrm{n}$-type poly-Si/c-Si sample.

Supporting Information). The film growth rate is around 6.6 $\mathrm{nm} / \mathrm{min}$. However, the amorphous, instead of preferably crystalline, state of as-deposited $\mathrm{BaSi}_{2}$ (Figure S2) prohibits its direct employment into practical thin-film solar cells. Thus, a subsequent thermal crystallization process was implemented. As-deposited samples were annealed at temperatures $\left(T_{\mathrm{a}}\right)$ ranging from 550 to $750{ }^{\circ} \mathrm{C}$. Fused silica substrates here were utilized because of the high $T_{\mathrm{a}}$. Annealing duration $\left(t_{\mathrm{a}}\right)$ was fixed at $90 \mathrm{~min}$ to ensure full crystallization. Here, samples are denoted as $\mathrm{BaSi}_{2}-T_{\mathrm{a}} / t_{\mathrm{a}}$, e.g., $\mathrm{BaSi}_{2}-\mathrm{RT} / 0$ (as-deposited), and $\mathrm{BaSi}_{2}-650 / 90\left(T_{\mathrm{a}}=650{ }^{\circ} \mathrm{C}\right.$ and $\left.t_{\mathrm{a}}=90 \mathrm{~min}\right)$.

Figure 1a shows the Raman spectra of annealed $\mathrm{BaSi}_{2}$ films acquired by a $633 \mathrm{~nm}$ red laser. Typically, there are five Raman bands corresponding to the vibration of the $\left[\mathrm{Si}_{4}\right]^{4-}$ cluster in $\mathrm{BaSi}_{2}$, which are assigned to three vibrational modes, namely, $\mathrm{E}$ $\left(\sim 276 \mathrm{~cm}^{-1}\right.$ and $\left.\sim 293 \mathrm{~cm}^{-1}\right), \mathrm{F}_{2}\left(\sim 355 \mathrm{~cm}^{-1}\right.$ and $\sim 376$ $\left.\mathrm{cm}^{-1}\right)$, and $\mathrm{A}_{1}\left(\sim 486 \mathrm{~cm}^{-1}\right) \cdot{ }^{39,40}$ As shown in Figure 1a, only $\mathrm{BaSi}_{2}-650 / 90$ and $\mathrm{BaSi}_{2}-700 / 90$ display sharper bands with fairly strong intensities, while bands of other samples annealed at lower $T_{\mathrm{a}}\left(\mathrm{BaSi}_{2}-550 / 90\right.$ and $\left.\mathrm{BaSi}_{2}-600 / 90\right)$ present less distinguishable vibration bands.

Full width at half-maximum (fwhm) values of the strongestintensity $\mathrm{A}_{1}$ band $\left(\sim 486 \mathrm{~cm}^{-1}\right)$ are calculated to quantitatively study the crystalline quality. ${ }^{28,41}$ A lower fwhm value refers to a better crystalline quality. As shown in Figure 1a, fwhm values decreased from 11.6 to $9.9 \mathrm{~cm}^{-1}$ by increasing $T_{\mathrm{a}}$ from 550 to $700{ }^{\circ} \mathrm{C}$. This implies an enhancement of crystallization degree at higher $T_{\mathrm{a}}$ (but lower than $750{ }^{\circ} \mathrm{C}$ ). Nevertheless, the higher $T_{\mathrm{a}}\left(\geq 650{ }^{\circ} \mathrm{C}\right)$, on the other hand, causes the formation of $\mathrm{Si}$ nanocrystals (NCs), indicated by the band at $\sim 519 \mathrm{~cm}^{-1} .42,43$ Even worse is the sample $\mathrm{BaSi}_{2}-750 / 90$, which only presents a Si NC band.

It should be emphasized that Raman spectroscopy only reflects the superficial structure information due to the limited laser penetration depth. For a deeper insight of sample structures, a Raman depth-profiling method is then established by applying both red $(633 \mathrm{~nm})$ and green $(514 \mathrm{~nm})$ lasers to measure from either the film or substrate side (section S4, Supporting Information). Accordingly, an inhomogeneous structure of $\mathrm{BaSi}_{2}-650 / 90$ is portrayed by Figure $1 \mathrm{~b}$. An obvious change of Raman spectra, from surface to bottom, can be observed. Intensity ratios between $A_{1}$ and $S i$ bands $I\left(A_{1}\right)$ / $I(\mathrm{Si})$ are calculated to roughly quantify concentration ratios between $\mathrm{BaSi}_{2}$ and $\mathrm{Si} \mathrm{NCs}$ within detected regions. Here, we see an increase of $I\left(\mathrm{~A}_{1}\right) / I(\mathrm{Si})$ from 0.64 at the top-surface region to 2.46 at the buried bottom, implying a composition evolution. To be explicit, less $\mathrm{BaSi}_{2}$ remains at the surface region, while Si NCs are inclined to form and accumulate at the surface.

Figure 1c presents the XRD patterns of annealed samples. Most of the strong diffraction peaks are related to orthorhombic $\mathrm{BaSi}_{2}$, which is consistent with the Raman spectroscopy and further confirms $\mathrm{BaSi}_{2}$ crystallization. In addition to the orthorhombic phase, cubic and hexagonal $\mathrm{BaSi}_{2}$ can also be observed. Cubic and hexagonal phases are reported to be metastable in ambient pressure, and form at hightemperature-pressure conditions (up to $1000{ }^{\circ} \mathrm{C}$ and 1 GPa). ${ }^{44-46}$ The existence of those phases may result from the 
high energy of charged particles $(\mathrm{Ba}$ and $\mathrm{Si}$ ) in the sputtering process. The existences of other low-concentration (less than $7 \%$ of the analyzed film) barium silicon compounds such as $\mathrm{Ba}_{5} \mathrm{Si}_{3}$ can also be noticed, the diffraction peak intensities of which decrease with the increase of $T_{a}$. Formation mechanisms of those phases and compositions remain to be uncovered for the goal of obtaining single-phase orthorhombic $\mathrm{BaSi}_{2}$.

It is worth noting that $\mathrm{BaSi}_{2}$ diffraction peaks can also be observed in $\mathrm{BaSi}_{2}-750 / 90$, in which sample $\left[\mathrm{Si}_{4}\right]^{4-}$ Raman vibrational bands cannot be collected from either the film or substrate side (Figure S4). This suggests the existence of a $\mathrm{BaSi}_{2}$ layer that is sandwiched between two thick non- $\mathrm{BaSi}_{2}$ layers in the $\mathrm{BaSi}_{2}-750 / 90$. The possible amorphous and/or microcrystalline state of non- $\mathrm{BaSi}_{2}$ layers prohibits their being detected by XRD or Raman. Additionally, the absence of $\left[\mathrm{Si}_{4}\right]^{4-}$ Raman bands indicates that the higher annealing is presumed to enhance the non- $\mathrm{BaSi}_{2}$ layer growth.

Auger electron spectroscopy (AES) was then employed to determine the elemental composition and structure. Because of the requirement of conducting substrates for measurements, crystalline silicon $(c-\mathrm{Si})$ wafers instead of fused silica substrates were utilized here. Prior to the $\mathrm{BaSi}_{2}$ growth, $c$-Si substrates were coated with interlayers, including $\mathrm{SiO}_{2}$ and p-, and n-type polycrystalline silicon (poly-Si). ${ }^{47}$ Employments of the interlayer can avoid the influence of $c$-Si orientation on film growth, and make it possible to study the case of glass substrates.

Figure 2a displays the depth elemental concentrations of the as-deposited $\mathrm{BaSi}_{2}$ film with a structure of $\left(\mathrm{BaSi}_{2}-\mathrm{RT} / 0\right)$ / $\mathrm{SiO}_{2} / c$-Si. The layer structure is quite distinguishable, including the native oxide layer (Layer I, ca. $5 \mathrm{~nm}$, Figure S7), the $\mathrm{BaSi}_{2}$ (Layer II, ca. $450 \mathrm{~nm}$ ), the $\mathrm{SiO}_{2}$ interlayer (Layer III), and the $c$-Si substrate (Layer IV). A constant ratio of $\mathrm{Ba}: \mathrm{Si}=1: 2$ throughout the Layer II reflects the excellent stoichiometry control of the sputtering technique. In addition, no obvious interdiffusion phenomenon can be observed within the $\mathrm{BaSi}_{2}$-RT/0.

However, the existence of $10 \%$ oxygen that uniformly distributes throughout the Layer II can also be observed. There are three potential sources of the oxygen, including oxygen diffusing from $\mathrm{SiO}_{2}$, the native oxidation, and the residual oxygen in the chamber. First, thermodynamic nonequilibrium states of atoms during the sputtering process can induce the oxygen diffusion at the $\mathrm{BaSi}_{2} / \mathrm{SiO}_{2}$ interface. On the other hand, the amorphous nature of the as-deposited film, containing a high density of defects and disorder structures, may enhance the chance for oxygen (in the air) bonding with $\mathrm{Ba}$ and $\mathrm{Si}$ during the sample storage. However, the absence of oxygen concentration gradient near $\mathrm{BaSi}_{2} / \mathrm{SiO}_{2}$ and air $/ \mathrm{BaSi}_{2}$ interfaces suggests that oxygen is less likely to originate from the two above-discussed sources. Another possible source is the residual $\mathrm{O}_{2}$ and moisture in the deposition chamber. Given that the base pressure of deposition chamber is around $2 \times$ $10^{-4} \mathrm{~Pa}$, the $\mathrm{O}_{2}$ partial pressure, as a result, is in the order of $10^{-5} \mathrm{~Pa}$. This ensures a sufficient number of oxygen atoms for incorporation in $\mathrm{BaSi}_{2}$ films. Because of its incorporation with $\mathrm{BaSi}_{2}$ during deposition, the oxygen here is denoted as internal O. Not only in the case of sputtering, similar oxygen incorporation phenomena have also been reported with epitaxial and evaporated $\mathrm{BaSi}_{2}$, which are executed at even lower pressures (on the order of $10^{-5} \mathrm{~Pa}$ ). ${ }^{16,35,48}$ The existence of those internal $\mathrm{O}$ atoms does not alter the composition uniformity of sputtered $\mathrm{BaSi}_{2}$. Nevertheless, it is currently hard to assert the effects of internal $\mathrm{O}$ on $\mathrm{BaSi}_{2}$ properties, which needs further study.

Figure $2 \mathrm{~b}$ shows the elemental structure of the $\mathrm{BaSi}_{2}-650 / 90$ on the same $\mathrm{SiO}_{2} / c$-Si substrate. $\mathrm{BaSi}_{2}-650 / 90$ exhibits an inhomogeneous structure in which a Si-rich $\mathrm{BaSi}_{2}$ (Layer IV) is sandwiched between an oxide layer (Layers I-III) and an interdiffusion layer (interfacial region between Layers IV and $\mathrm{V})$. Such a layered structure is consistent with Raman and XRD observations.

A high concentration of $\mathrm{O}$ at surface region is the outcome of intensive surface oxidation. We denote the $\mathrm{O}$ here as external $\mathrm{O}$ to distinguished from the $\mathrm{O}$ incorporating to $\mathrm{BaSi}_{2}$ during the deposition. The oxide layer (holding a high $\mathrm{O}$ concentration) can be further divided into three sublayers illustrated in Figure $2 \mathrm{~b}$. Within the Layers I and II, only $\mathrm{Si}(\mathrm{O})$, $\mathrm{Ba}$, and $\mathrm{O}$ can be detected, indicating the composition of $\mathrm{SiO}_{2}$ and $\mathrm{BaO}$. The concentration of $\mathrm{SiO}_{2}$ increases throughout the Layer I, and eventually reaches a $\mathrm{BaO}: \mathrm{SiO}_{2}$ ratio of 2:1 (Layer II). Composition transition starts from the Layer III (near the oxide $/ \mathrm{BaSi}_{2}$ interfacial region). Accompanied with the upward Si curve in the Layer III, both $\mathrm{BaO}$ and $\mathrm{SiO}_{2}$ start to decrease while keeping $\mathrm{BaO}: \mathrm{SiO}_{2}=2: 1$. The accumulation of $\mathrm{Si}$ in the Layer III results in the formation of Si NC (Figure 2b). Hence, the oxide layer (Layers I-III) presents a composition of $\mathrm{BaO}$ and $\mathrm{SiO}_{2}$, together with $\mathrm{Si}$ NCs. A higher annealing temperature, i.e., $750{ }^{\circ} \mathrm{C}$, can promote the surface oxidation inducing a thicker oxide layer containing higher-concentration $\mathrm{Si}$ NCs. This explains the Raman spectrum of $\mathrm{BaSi}_{2}-750 / 90$ (Figure 1a), which only holds a Si NCs peak.

The phenomena of Si accumulation can also be observed on the other side of the "sandwich", indicated in Figure 2b. This can be the consequence of the diffusion of $\mathrm{Ba}$ into the $\mathrm{SiO}_{2}$ interlayer (Layer $\mathrm{V}$ ). Ba unveils a relatively high diffusivity into $\mathrm{SiO}_{2}$ and distributes throughout the Layer V. This accumulated $\mathrm{Si}$ also formed $\mathrm{Si}$ NCs, which is consistent with the Raman spectrum obtained from the substrate side (Figure 1c). Such $\mathrm{Ba}$ diffusion can be effectively suppressed by poly-Si interlayers. No Ba presents itself in the n-type poly-Si layer (Layer VI in Figure 2c). However, there is a relatively high concentration of $\mathrm{O}$ in the Layer $\mathrm{V}$. The absence of $\mathrm{Si}(\mathrm{O})$ here implies that it is a $\mathrm{Ba}-\mathrm{Si}-\mathrm{O}$ complex oxide rather than a mixture of $\mathrm{SiO}_{2}$ and $\mathrm{BaO}$. $\mathrm{O}$ atoms here can also be the internal $\mathrm{O}$, which may originate from the residual oxygen in the deposition chamber as well as $\mathrm{O}_{2}$ and/or oxygencontaining groups adhering to the poly-Si surface. The case of p-type poly-Si (B-doped) is almost similar (Figure S7), except for the disappearance of $\mathrm{B}$ within the poly-Si interlayer (and/or B concentration is under detection limit).

The surface oxidation together with interfacial diffusion phenomena leave a Si-rich $\mathrm{BaSi}_{2}$ layer in the center of the "sandwich". As illustrated in the Figure $2 \mathrm{~b}, \mathrm{Si}$ atomic concentration is far more than twice that of $\mathrm{Ba}$ (2Ba curve), especially near the interfacial (oxide $/ \mathrm{BaSi}_{2}$ and $\mathrm{BaSi}_{2} / \mathrm{SiO}_{2}$ ) regions. Not only the $\mathrm{Si}$ accumulations but also the $\mathrm{Ba}$ movement can be observed. Upon comparison of the overall Ba distribution in Figure 2a,b (also Figure 2c), the trend that Ba moves to the surface and substrate side after annealing is quite noticeable. Nevertheless, the internal oxygen still remains a constant concentration nearly $10 \%$ after annealing throughout the core region of the Layer IV $(250-450 \mathrm{~nm})$. This suggests a stable structure of O-incorporated $\mathrm{BaSi}_{2}$ in high temperatures. In addition, it needs to be emphasized that it is external $\mathrm{O}$ (from annealing atmosphere and $\mathrm{SiO}_{2}$ substrate) 

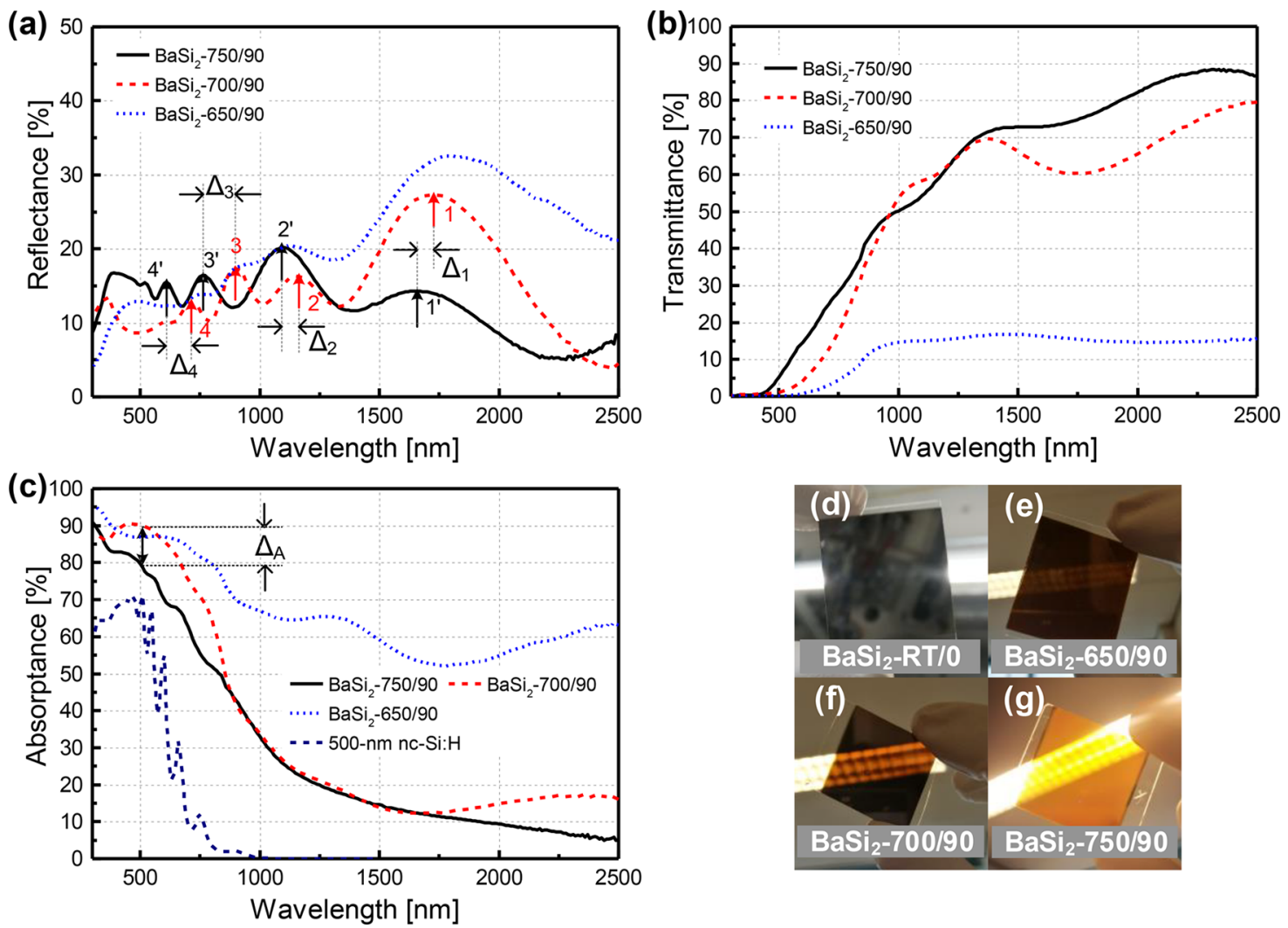

Figure 3. Wavelength-dependent (a) reflectance, (b) transmittance, and (c) absorptance curves of annealed $\mathrm{BaSi}_{2}$ thin films. Interference peak position shifts, i.e., $\Delta_{1}, \Delta_{2}, \Delta_{3}$, and $\Delta_{4}$, are indicated in part a. The absorptance was calculated as follows: absorptance $(\%)=100-$ reflectance $(\%)$ - transmittance $(\%)$. The simulated absorptance curve of $500 \mathrm{~nm}$ thick $n c$-Si:H film is presented as the reference. The absorptance difference between $\mathrm{BaSi}_{2}-700 / 90$ and $\mathrm{BaSi}_{2}-750 / 90\left(\Delta_{\mathrm{A}}\right)$ is illustrated in part c. Photo images of $(\mathrm{d}) \mathrm{BaSi}_{2}-\mathrm{RT} / 0,(\mathrm{e}) \mathrm{BaSi}_{2}-650 / 90,(\mathrm{f}) \mathrm{BaSi} \mathrm{i}_{2}-700 / 90$, and $(\mathrm{g})$ $\mathrm{BaSi}_{2}-750 / 90$.

rather than internal $\mathrm{O}$ (from residual air in the deposition chamber) that alters the composition uniformity of sputtered $\mathrm{BaSi}_{2}$. Further attempts to obtain uniform sputtered $\mathrm{BaSi}_{2}$ should be focused on the antioxidation/diffusion layer development, and poly-Si (and/or $a-S i$ ) can be regarded as a potential candidate.

Another phenomenon that should not be neglected is the slight shift of the boundary between the Layers II and III (Figure 2b,c, and Figure S8), while the thickness of oxide layer keeps constant $(\sim 200 \mathrm{~nm})$. The cross-section transmission electron microscopy (TEM) image in Figure $2 \mathrm{~d}$ provides clues for the variation. The Layer I shows a relatively distinguishable and flat boundary with a thickness $\sim 50 \mathrm{~nm}$. However, Layers II and III almost merge together and are hard to be distinguished from the $\mathrm{BaSi}_{2}$ layer. The variation in gray-scale near the oxide/ $\mathrm{BaSi}_{2}$ interfacial region suggests the nonuniform composition and/or structure distribution in this region. Therefore, there is a high chance to collect AES depth profiles with different sublayer thicknesses. Additionally, the highresolution TEM (HR-TEM) image of $\mathrm{BaSi}_{2}$ bulk (Figure 2f) together with the electron diffraction (ED) pattern (Figure 2e) reveal the polycrystalline and multiphase structure of $\mathrm{BaSi}_{2}-$ $650 / 60$.

Such a structure with a thick oxide layer prohibits material characterizations and the further application in PV solar cells. Figure $3 \mathrm{a}$ presents the wavelength-dependent reflectance curves of $\mathrm{BaSi}_{2}-650 / 90, \mathrm{BaSi}_{2}-700 / 90$, and $\mathrm{BaSi}_{2}-750 / 90$. Interference fringes in reflectance curves can result from the layered structure of high-temperature-annealed $\mathrm{BaSi}_{2}$ films.
Interference peak position shifts with the increase of $T_{\mathrm{a}}$ can also be observed. This can be caused by the oxide layer growth (bulk $\mathrm{BaSi}_{2}$ thickness decreasing) at higher $T_{\mathrm{a}}$. In addition, increasing $T_{\mathrm{a}}$ from 650 to $700{ }^{\circ} \mathrm{C}$ leads to a drastic enhancement of the transmittance (Figure $3 \mathrm{~b}$ ). This can be interpreted by the improvement of $\mathrm{BaSi}_{2}$ crystalline quality at higher $T_{a}$ (Figure 1a) and/or oxide layer $\left(\mathrm{SiO}_{2}\right.$ and $\left.\mathrm{BaO}\right)$ growth.

Figure $3 \mathrm{c}$ shows absorptance curves. $\mathrm{BaSi}_{2}$ films exhibit high absorptance as compared to hydrogenated nanocrystalline silicon ( $n c-\mathrm{Si}: \mathrm{H})$. However, metallic and/or defective phases (Figure $1 \mathrm{~b}$ ) induce an absorptance tail in the long wavelength range, and it can be attenuated by increasing $T_{\mathrm{a}}$. $\mathrm{BaSi}_{2}-700 / 90$ and $\mathrm{BaSi}_{2}-750 / 90$ then present obvious absorption edges. However, higher $T_{\mathrm{a}}$ up $750{ }^{\circ} \mathrm{C}$ in turn reduces the absorptance in the visible wavelength range. The absorptance difference between $\mathrm{BaSi}_{2}-700 / 90$ and $\mathrm{BaSi}_{2}-750 / 90$ reaches a maximum at a wavelength around $500 \mathrm{~nm}$, which is near the absorptance peak of $n c-S i: H$ (Figure 3c). Hence, such an absorptance difference can be a consequence of formations of a higher concentration of Si NCs and/or the thicker oxide layer at higher $T_{\mathrm{a}}$. Those optical properties are also consistent with appearances of samples (Figure $3 \mathrm{~d}-\mathrm{f}$ ), including the change of the transparency and brownish color (annealed samples).

Even though optical characterizations provide some information on annealed samples, it is hard to obtain the exact optical properties of bulk $\mathrm{BaSi}_{2}$ with the existence of such a layered structure (oxide and Si NCs). The same goes for the 

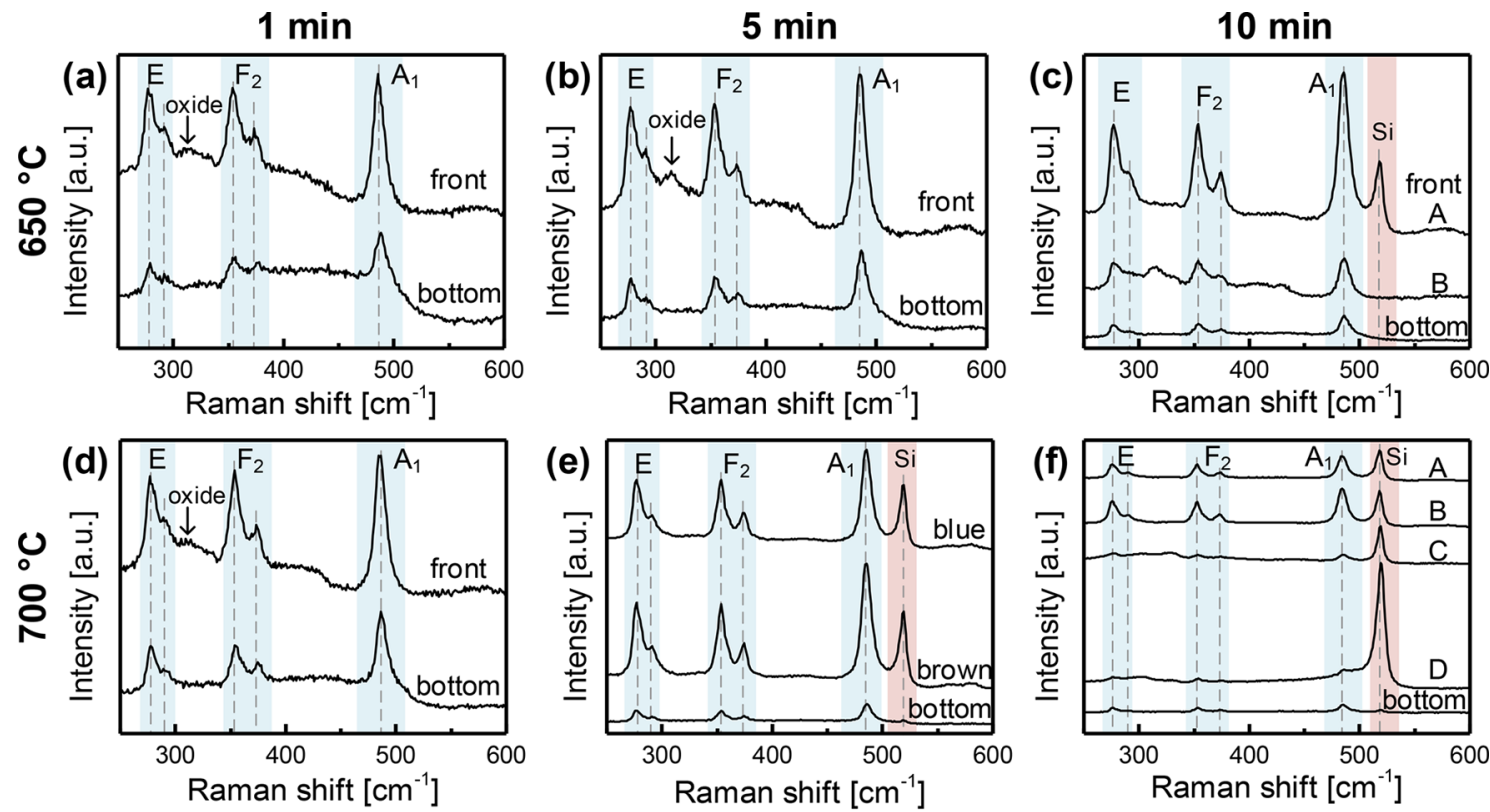

(g)

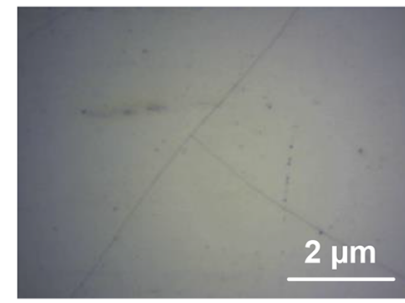

(h)

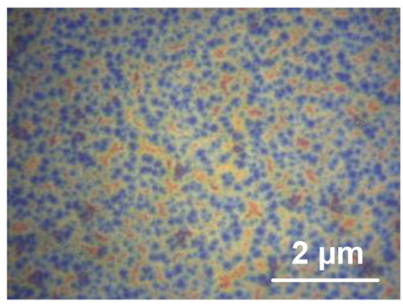

(i)

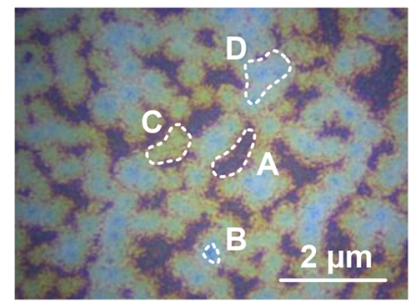

(j)
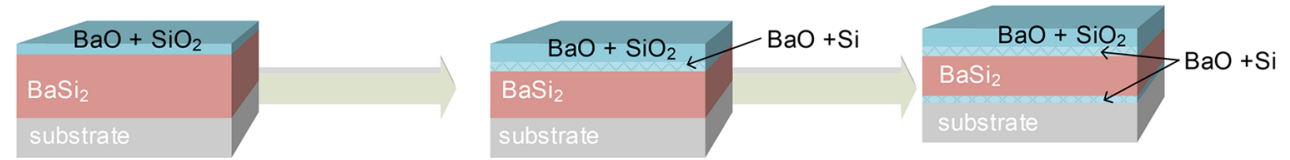

Figure 4. Raman spectra of (a) $\mathrm{BaSi}_{2}-650 / 1$, (b) $\mathrm{BaSi}_{2}-650 / 5$, (c) $\mathrm{BaSi}_{2}-650 / 10$, (d) $\mathrm{BaSi}_{2}-700 / 1$, (e) $\mathrm{BaSi}_{2}-700 / 5$, and (f) $\mathrm{BaSi}_{2}-700 / 10$. The vibrational band at $\sim 315 \mathrm{~cm}^{-1}$, indicated by arrows, refers to surface oxides. Optical microscope images of $(\mathrm{g}) \mathrm{BaSi}_{2}-700 / 1,(\mathrm{~h}) \mathrm{BaSi} \mathrm{i}_{2}-700 / 5$, and (i) $\mathrm{BaSi}_{2}-700 / 10$ were captured by the Raman setup. (j) Schematic representation of $\mathrm{BaSi}_{2}$ structural evolution in the time scale.

electrical properties. The thick oxide layer at the front side inhibits proper measurement due to high contact resistance.

Investigation on Sputtered $\mathrm{BaSi}_{2}$ Annealing Process. A deeper understanding on the mechanism of the abovediscussed structural transformation then is essential for sputtered $\mathrm{BaSi}_{2}$ quality-optimization and further applications. Hence, the annealing process is temporally investigated by the established Raman depth-profiling method (only $633 \mathrm{~nm}$ laser is employed here). Raman depth profiles of $\mathrm{BaSi}_{2}-650 / 1$, $\mathrm{BaSi}_{2}-650 / 5$, and $\mathrm{BaSi}_{2}-650 / 10$ are presented in Figure $4 \mathrm{a}-\mathrm{c}$, respectively. Vibration bands of $\left[\mathrm{Si}_{4}\right]^{4-}$ observed at all samples suggest the $\mathrm{BaSi}_{2}$ crystallization. Prolonging the $t_{\mathrm{a}}$ sharpens the vibration bands, indicating the promotion of crystallization. It is additionally reflected by the decrease of absorptance (Figure S8c). The surface oxidation also happens, implicated by the oxide band $\sim 315 \mathrm{~cm}^{-1}$ (Figure $4 \mathrm{a}, \mathrm{b}$ ). ${ }^{49}$ In addition, Raman spectra of some specific regions at the $\mathrm{BaSi}_{2}-650 / 10$ surface present a Si band (Figure 4c and Figure S9).

A more significant surface morphological change is observed with $T_{\mathrm{a}}=700{ }^{\circ} \mathrm{C}$ (Figure $4 \mathrm{~g}-\mathrm{i}$ ). Cracks at the sample $\mathrm{BaSi}_{2}-$ $700 / 1$, probably caused by the thermal expansion coefficient mismatch, disappear by prolonging the $t_{\mathrm{a}}$. This can be the result of the surface composition variation, reflected by the surface color change (Figure 4g,h). However, we cannot assert the situation of cracks below the surface region, which remains to be investigated.

Prolonging the $t_{\mathrm{a}}$ induces a nonuniform surface, including the appearance and composition. Accompanying the formation of blue and brown regions at the surface of $\mathrm{BaSi}_{2}-700 / 5$, the $\mathrm{Si}$ Raman band can be noticed in the surface region (Figure $4 \mathrm{e}$ ). However, the $\mathrm{Si}$ band in the bottom region is less distinguishable. Further extending the $t_{\mathrm{a}}$ to $10 \mathrm{~min}$ results in area expansions of blue and brown regions (Figure 4i). Moreover, some regions, i.e., $\mathrm{C}$ and $\mathrm{D}$ regions in Figure $4 \mathrm{i}$, only exhibit strong Si bands in Raman spectra (Figure 4f). In addition, the $\mathrm{Si}$ band appears at the bottom of $\mathrm{BaSi}_{2}-700 / 10$ (Figure S10).

Accordingly, the annealing process of $\mathrm{BaSi}_{2}$, in respect to temporal structure and composition evolutions, can be roughly divided into three phases: (i) Si NC free and uniform surface oxidation, (ii) Si NC formation involving nonuniform surface oxidation, and (iii) Si NC formation in the bottom region, as illustrated by Figure $4 \mathrm{j}$.

Oxidation-Induced Structure Transformation of $\mathrm{BaSi}_{2}$. Previous research has credited the $\mathrm{BaSi}_{2}$ oxidation and $\mathrm{Si}$ NC formation to the following reaction:

$$
2 \mathrm{BaSi}_{2}+\mathrm{O}_{2} \rightarrow 2 \mathrm{BaO}+4 \mathrm{Si} \quad \Delta_{\mathrm{r}} \mathrm{G}=-841.87 \mathrm{~kJ} / \mathrm{mol}
$$


by which $\mathrm{Si}$ atoms (or $\left[\mathrm{Si}_{4}\right]^{4-}$ ) are isolated and form $\mathrm{Si}$ NCs. ${ }^{49,50} \Delta_{\mathrm{r}} G$ is the change in Gibbs free energy of the reaction at the temperature of $650{ }^{\circ} \mathrm{C}(923 \mathrm{~K}) . \Delta_{\mathrm{r}} G$ is calculated by the standard formation enthalpy and entropy of the reactant and resultant. ${ }^{32}$ The thermodynamic properties of $\mathrm{BaSi}_{2}$ powder here are utilized. ${ }^{51,52}$

Equation 1 can hardly explain the structural transformation of $\mathrm{BaSi}_{2}$ in either the depth or time scale as described before. By such a single-stage reaction, $\mathrm{Si} \mathrm{NCs}$ are supposed to distribute uniformly in the surface region, and should be formed in the initial oxidation phase. Herein, an oxidationinduced structure transformation mechanism is proposed and illustrated in Scheme 1, which is based on the above structure and interface investigations. The single-stage reaction (eq 1) is elaborated to a multistage variation including three major phases.

Scheme 1. Schematic Representation of Oxidation-Induced Structure Transformation of $\mathrm{BaSi}_{2}$ Films during the HighTemperature Annealing Process (Note That the Diagram Does Not Represent the Real Microstructures of the Materials)

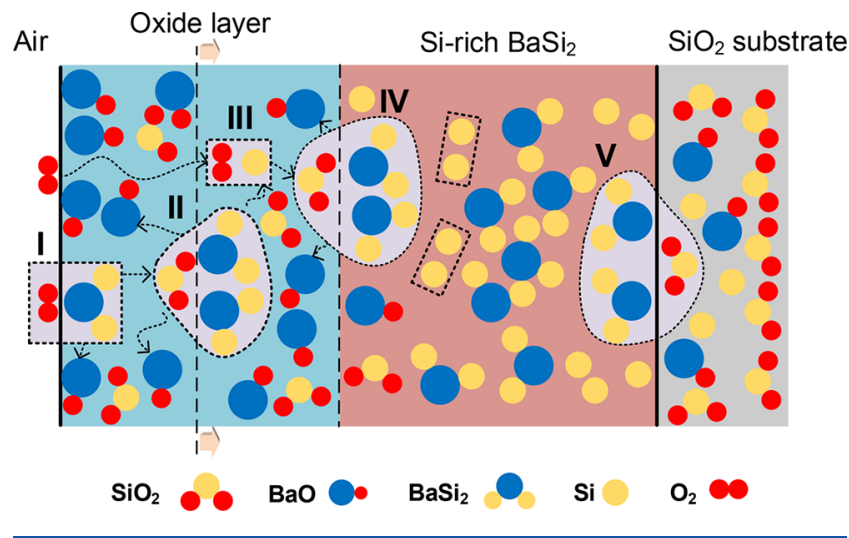

Initial Oxidation Phase at the Air/BaSi ${ }_{2}$ Interface. In this first-stage phase, the film surface is rapidly oxidized by the residual $\mathrm{O}_{2}$ (as well as the moisture) in the $\mathrm{N}_{2}$ annealing ambient environment (process I in Scheme 1).

$$
2 \mathrm{BaSi}_{2}+3 \mathrm{O}_{2} \rightarrow 2 \mathrm{BaO}+4 \mathrm{SiO}_{2} \quad \Delta_{\mathrm{r}} \mathrm{G}=-4189.53 \mathrm{~kJ} / \mathrm{mol}
$$

Consequently, the film surface is covered with a thin oxide layer, mainly consisting of $\mathrm{BaO}$ and $\mathrm{SiO}_{2}$. Additionally, the slight trace of $\mathrm{C}$ detected by AES (section S12, Supporting Information) in the surface can be regarded as the outcome of the reaction (not indicated in Scheme 1).

$$
\begin{gathered}
\mathrm{BaSi}_{2}+5 \mathrm{H}_{2} \mathrm{O}(\mathrm{g})+\mathrm{CO}_{2} \rightarrow \mathrm{BaCO}_{3}+2 \mathrm{SiO}_{2}+5 \mathrm{H}_{2} \\
\Delta_{\mathrm{r}} G=-505.09 \mathrm{~kJ} / \mathrm{mol}
\end{gathered}
$$

The crystallization process of $\mathrm{BaSi}_{2}$ does initiate at the same time. Hence, $\mathrm{BaSi}_{2}$ vibrational bands together with an oxide band can be found in Raman spectra of $\mathrm{BaSi}_{2}-650 / 1, \mathrm{BaSi}_{2}$ 650/5, and $\mathrm{BaSi}_{2}-700 / 1$ (Figure 4a,b,d).

Oxide Layer Growth Phase at the Oxide/BaSi Interface. In addition to the surface oxidation, the resultant $\mathrm{SiO}_{2}$ also provides an additional path for oxide/ $\mathrm{BaSi}_{2}$ interfacial front advancing to the deeper region (process II in Scheme 1), which is defined as

$$
2 \mathrm{BaSi}_{2}+\mathrm{SiO}_{2} \rightarrow 2 \mathrm{BaO}+5 \mathrm{Si} \quad \Delta_{\mathrm{r}} G=-99.65 \mathrm{~kJ} / \mathrm{mol}
$$

Actually, it is also an oxidation reaction of $\mathrm{BaSi}_{2}$, due to the electron loss of $\mathrm{Si}$ in $\mathrm{BaSi}_{2}$. Indeed, the evolving oxide/ $\mathrm{BaSi}_{2}$ interfacial front can be roughly tracked with simultaneous recording of depth Raman spectroscopy. Extending the annealing duration increases the concentration of isolated $\mathrm{Si}$ atoms. Those $\mathrm{Si}$ atoms can either form $\mathrm{Si} \mathrm{NCs}$, verified by the $\mathrm{Si}$ band in Raman spectra, or be oxidized to $\mathrm{SiO}_{2}$ by the $\mathrm{O}_{2}$ molecules that manage to penetrate through the thin oxide layer (process III in Scheme 1), reflected by the $\mathrm{Si}(\mathrm{O})$ curve upward trend in Layer I of Figure 2b,c.

More $\mathrm{BaSi}_{2}$ is depleted by the process IV. Consequently, the oxide layer grows thicker, which inhibits the further penetration of $\mathrm{O}_{2}$ as well as the subsequent formation of $\mathrm{SiO}_{2}$. This is the reason for the $\mathrm{SiO}_{2}$ concentration decrease within the Layer III (Figure 2b,c). In this way, Si atoms (in the form of $\mathrm{SiO}_{2}$ ) in the oxide layer are gradually yet only partially replaced by $\mathrm{Ba}$ atoms (forming $\mathrm{BaO}$ ) from the buried $\mathrm{BaSi}_{2}$ layer. Figuratively speaking, the $\mathrm{Ba}$ atoms are dragged to the upper oxide layer by the oxidation reactions. Hence, a higher concentration of $\mathrm{Ba}$ in the surface region is detected by AES spectroscopy (Figure $2 \mathrm{~b}$ ), while the $\mathrm{Si}$ atomic concentration can only reach nearly half of that of $\mathrm{Ba}$. Note that the movement of $\mathrm{Ba}$, in turn, leads to $\mathrm{Si}$ atom accumulation in the $\mathrm{BaSi}_{2}$ layer, especially near the oxide $/ \mathrm{BaSi}_{2}$ interface. Moreover, such $\mathrm{SiO}_{2}$-triggered oxide layer growth results in the boundary variation between Layers II and III (Figure 2b,c).

Oxygen-Driven Ba Diffusion at the $\mathrm{BaSi}_{2} / \mathrm{SiO}_{2}$ Interface. With a longer $t_{\mathrm{a}}$, Si vibration bands appear in the Raman spectra in the case of detection from the substrate side. In such conditions, eq 4 is valid at the $\mathrm{BaSi}_{2} / \mathrm{SiO}_{2}$ interface. Similarly, isolated $\mathrm{Si}$ atoms formed $\mathrm{Si} \mathrm{NCs}$, interpreting the $\mathrm{Si}$ atom accumulation near the $\mathrm{BaSi}_{2} / \mathrm{SiO}_{2}$ interface (Figure $2 \mathrm{~b}$ ) as well as the consequent $\mathrm{Ba}$ diffusion into $\mathrm{SiO}_{2}$. In spite of the slight $\mathrm{Ba}$ diffusion within the thin oxide layer, no $\mathrm{Ba}$ atom can be detected throughout the n-type poly-Si interlayer in Figure 2c. Hence, we can assert that it is the oxygen $\left(\mathrm{in}_{\mathrm{SiO}_{2}}\right)$ that drives the $\mathrm{Ba}$ diffusion.

The oxidation-induced structure transformation mechanism allows interpretation of both composition and structure transitions of $\mathrm{BaSi}_{2}$ thin films occurring at higher $T_{a}$, i.e., 650,700 , and $750{ }^{\circ} \mathrm{C}$. However, cases of lower $T_{a}$, such as 550 and $600{ }^{\circ} \mathrm{C}$, are more challenging to explain. Equations $1-4$ can theoretically occur at $T_{\mathrm{a}}=550$ and $600{ }^{\circ} \mathrm{C}$. Nevertheless, no distinguishable layered structure or $\mathrm{Si} \mathrm{NCs}$ can be observed in samples $\mathrm{BaSi}_{2}-550 / 90$ and $\mathrm{BaSi}_{2}-660 / 90$ (Figures $1 \mathrm{a}$ and 2). This may result from the low-degree crystallization of $\mathrm{BaSi}_{2}$ (Figure 1a) and the existence of impurities (Figure 1b). One can speculate that the $\mathrm{BaSi}_{2}$ crystal structure transition from amorphous to crystalline state also changes the thermodynamic properties of the material. Those property changes may consequently suppress the above-mentioned structure transformation process. Further research remains to be conducted, which can lay an alternative path to enhance thermodynamic stability of $\mathrm{BaSi}_{2}$ for a wider-processing-temperature PV application.

\section{CONCLUSIONS}

In summary, our work established an oxidation-induced structure transformation mechanism, based on structural and interfacial investigations on sputtered $\mathrm{BaSi}_{2}$ films. Polycrystal- 
line $\mathrm{BaSi}_{2}$ thin films are obtained via RF sputtering followed by a postannealing process. An oxidation-induced structure transformation mechanism is proposed to interpret the transition from once homogeneous and stoichiometric films to a layered and multiphase structure. This is not limited to the sputtering case but can be extended to epitaxial and evaporated $\mathrm{BaSi}_{2}$ thin films related to high-temperature processes. In addition, the established Raman spectroscopy depth-profiling method provides a fast and facile path for structural analysis of $\mathrm{BaSi}_{2}$ films. Even though the sputtering technique is proven to be a suitable method for $\mathrm{BaSi}_{2}$ thin-film synthesis, more efforts still need to be put on quality improvement of sputtered $\mathrm{BaSi}_{2}$, especially on the development of antioxidation/diffusion approaches. This fundamental knowledge on structural transformations and complex interfacial activities is significant for further quality control and interface engineering on $\mathrm{BaSi}_{2}$ films toward high-efficiency solar cells. With respect to device developments, interfacial phenomena discussed in this research also provide important information for a $\mathrm{BaSi}_{2}$-based thin-film solar cell architecture design.

\section{EXPERIMENTAL SECTION}

Synthesis of $\mathrm{BaSi}_{2}$ Thin Films. An RF magnetron sputtering setup (Kurt J. Lesker) was applied for the growth of $\mathrm{BaSi}_{2}$ films. A stoichiometric ceramic $\mathrm{BaSi}_{2}$ target (Tosoh) was installed. After the deposition chamber was pumped to less than $2 \times 10^{-4} \mathrm{~Pa}$, Ar gas flow was introduced into the chamber. The background pressure was maintained at $1 \mathrm{~Pa}$ during the whole growth process. Plasma power of $50 \mathrm{~W}$ was applied. Prior to the growth, a presputtering process was carried out for $10 \mathrm{~min}$. The samples were deposited on either glass or silicon wafer substrates. After the sputtering process, the deposited $\mathrm{BaSi}_{2}$ films were subsequently annealed for $90 \mathrm{~min}$ in a nitrogen atmosphere. Annealing temperatures ranged from 550 to $750{ }^{\circ} \mathrm{C}$ with a step of $50{ }^{\circ} \mathrm{C}$.

Substrate Preparations. Glass and silicon wafer substrates were utilized in the research. Glass substrates including alkali-free (Corning EAGLE XG) glass and Heraeus Spectrosil 2000 fused silica were cleaned by ultrasonication in acetone and successively in isopropanol. $\mathrm{SiO}_{2}$ and $\mathrm{n}$ - and p-type poly-Si interlayers were deposited on the $c$-Si substrate before the $\mathrm{BaSi}_{2}$ growth. $\mathrm{SiO}_{2}$ layers were formed by thermal oxidation with the wet method at $1050{ }^{\circ} \mathrm{C}$. In terms of poly-Si, intrinsic $a$-Si layers were deposited in a Tempress low-pressure chemical vapor deposition (LP-CVD) tube furnace. Subsequently, P or $\mathrm{B}$ atoms were implanted into the $a$-Si layer by a Varian Implanter E500HP. Doped poly-Si layers were obtained by following hightemperature annealing at $\mathrm{N}_{2}$ atmosphere.

Characterizations of $\mathrm{BaSi}_{2}$ Thin Films. The thickness of the asdeposited sample was measured by the spectroscopic ellipsometry (SE, J.A.Woollam Co.). Raman spectra were acquired by an InVia Raman microscope (Renishaw) with excitation wavelengths of 514 and $633 \mathrm{~nm}$. The XRD patterns were obtained by an automatic powder X-ray diffractometer X'Pert Pro equipped with an ultrafast linear semiconductor detector PIXcel and on a point proportional detector. $\mathrm{Cu} \mathrm{K} \alpha$ radiation $(\lambda=0.154 \mathrm{~nm})$ was used as an X-ray source. The $\mathrm{X}$-ray incidence angle $\omega$ was fixed at $0.5^{\circ}$. The wavelength-dependent reflectance and transmittance $(R / T)$ were measured by a PerkinElmer Lambda 950 spectrometer. Elemental composition analysis was carried out in a Jeol JAMP 9510-F Auger microprobe at $10 \mathrm{keV}$ energy with tilt angle of $30^{\circ}$. During sputtering cycles, $1000 \mathrm{eV} \mathrm{Ar}^{+}$ions were utilized. The film cross-section images and ED patterns were acquired by a TEM (JEOL JEM-2200FS).

\section{ASSOCIATED CONTENT}

\section{S Supporting Information}

The Supporting Information is available free of charge on the ACS Publications website at DOI: 10.1021/acsaem.8b00486.
Detailed experimental methods, thickness distribution, Raman spectra, crystallite sizes, microscope images, and AES spectra (PDF)

\section{AUTHOR INFORMATION}

\section{Corresponding Author}

*E-mail: y.tian@tudelft.nl.

ORCID ${ }^{\circ}$

Yilei Tian: 0000-0003-0042-5896

\section{Author Contributions}

The manuscript was written through contributions of all authors. All authors have given approval to the final version of the manuscript.

\section{Notes}

The authors declare no competing financial interest.

\section{ACKNOWLEDGMENTS}

The authors are indebted to Dr. Guangtao Yang and Gianluca Limodio for substrate preparations and would like to thank Martijn Tijssen and Stefaan G.M. Heirman for daily technical equipment support. Y.T. acknowledges financial support from the China Scholarship Council.

\section{REFERENCES}

(1) Goetzberger, A.; Hebling, C.; Schock, H. W. Photovoltaic Materials, History, Status and Outlook. Mater. Sci. Eng., R 2003, 40, $1-46$.

(2) Wadia, C.; Alivisatos, A. P.; Kammen, D. M. Materials Availability Expands the Opportunity for Large-scale Photovoltaics Deployment. Environ. Sci. Technol. 2009, 43, 2072-2077.

(3) Green, M. A.; Bremner, S. P. Energy Conversion Approaches and Materials for High-efficiency Photovoltaics. Nat. Mater. 2017, 16, $23-34$.

(4) Kurtz, S.; Haegel, N.; Sinton, R.; Margolis, R. A New Era for Solar. Nat. Nat. Photonics 2017, 11, 3-5.

(5) Suemasu, T. Exploring the Possibility of Semiconducting $\mathrm{BaSi}_{2}$ for Thin-film Solar Cell Applications. Jpn. J. Appl. Phys. 2015, 54, 07JA01.

(6) Suemasu, T.; Usami, N. Exploring the Potential of Semiconducting $\mathrm{BaSi}_{2}$ for Thin-film Solar Cell Applications. J. Phys. D: Appl. Phys. 2017, 50, 023001.

(7) Goebel, T.; Prots, Y.; Haarmann, F. Refinement of the Crystal Structure of Dibarium Tetrasilicide, $\mathrm{Ba}_{2} \mathrm{Si}_{4}$. Z. Kristallogr. - New Cryst. Struct. 2009, 224, 7-8.

(8) Kumar, M.; Umezawa, N.; Zhou, W.; Imai, M. Barium Disilicide as a Promising Thin-film Photovoltaic Absorber: Structural, Electronic, and Defect Properties. J. Mater. Chem. A 2017, 5, 25293-25302.

(9) Schäfer, H.; Janzon, K.; Weiss, A. BaS $\mathrm{B}_{\mathrm{i} 2}$, a Phase with Discrete $\mathrm{Si}_{4}$ Tetrahedra. Angew. Chem., Int. Ed. Engl. 1963, 2, 393-394.

(10) Morita, K.; Inomata, Y.; Suemasu, T. Optical and Electrical Properties of Semiconducting $\mathrm{BaSi}_{2}$ Thin Films on Si Substrates Grown by Molecular Beam Epitaxy. Thin Solid Films 2006, 508, 363366.

(11) Nishii, T.; Mizuno, T.; Mori, Y.; Takarabe, K.; Imai, M.; Kohara, S. X-ray Diffraction Study of Amorphous Phase of $\mathrm{BaSi}_{2}$ under High Pressure. Phys. Status Solidi B 2007, 244, 270-273.

(12) Kumar, M.; Umezawa, N.; Imai, M. $\mathrm{BaSi}_{2}$ as a Promising Lowcost, Earth-abundant Material with Large Optical Activity for Thinfilm Solar Cells: A Hybrid Density Functional Study. Appl. Phys. Express 2014, 7, 071203.

(13) Kumar, M.; Umezawa, N.; Imai, M. $(\mathrm{Sr}, \mathrm{Ba})(\mathrm{Si}, \mathrm{Ge})_{2}$ for Thinfilm Solar-cell Applications: First-principles Study. J. Appl. Phys. 2014, $115,203718$. 
(14) Hara, K. O.; Nakagawa, Y.; Suemasu, T.; Usami, N. Realization of Single-phase $\mathrm{BaSi}_{2}$ Films by Vacuum Evaporation with Suitable Optical Properties and Carrier Lifetime for Solar Cell Applications. Jpn. J. Appl. Phys. 2015, 54, 07JE02.

(15) Toh, K.; Saito, T.; Suemasu, T. Optical Absorption Properties of $\mathrm{BaSi}_{2}$ Epitaxial Films Grown on a Transparent Silicon-on-insulator Substrate Using Molecular Beam Epitaxy. Jpn. J. Appl. Phys. 2011, 50, 068001.

(16) Du, W.; Takabe, R.; Yachi, S.; Toko, K.; Suemasu, T. Enhanced Spectral Response of Semiconducting $\mathrm{BaSi}_{2}$ Films by Oxygen Incorporation. Thin Solid Films 2017, 629, 17-21.

(17) Hara, K. O.; Usami, N.; Nakamura, K.; Takabe, R.; Baba, M.; Toko, K.; Suemasu, T. Determination of Bulk Minority-carrier Lifetime in $\mathrm{BaSi}_{2}$ Earth-abundant Absorber Films by Utilizing a Drastic Enhancement of Carrier Lifetime by Post-growth Annealing. Appl. Phys. Express 2013, 6, 112302.

(18) Takabe, R.; Hara, K. O.; Baba, M.; Du, W.; Shimada, N.; Toko, K.; Usami, N.; Suemasu, T. Influence of Grain Size and Surface Condition on Minority-carrier Lifetime in Undoped $\mathrm{n}-\mathrm{BaSi}_{2}$ on Si(111). J. Appl. Phys. 2014, 115, 193510.

(19) Shaalan, N.; Hara, K.; Trinh, C.; Nakagawa, Y.; Usami, N. Simple Method for Significant Improvement of Minority-carrier Lifetime of Evaporated $\mathrm{BaSi}_{2}$ Thin Film by Sputtered- $\mathrm{AlO}_{\mathrm{x}}$ Passivation. Mater. Sci. Semicond. Process. 2018, 76, 37-41.

(20) Yachi, S.; Takabe, R.; Takeuchi, H.; Toko, K.; Suemasu, T. Effect of Amorphous Si Capping Layer on the Hole Transport Properties of $\mathrm{BaSi}_{2}$ and Improved Conversion Efficiency Approaching $10 \%$ in P-BaSi 2 /n-Si Solar Cells. Appl. Phys. Lett. 2016, 109, 072103.

(21) Tsukahara, D.; Yachi, S.; Takeuchi, H.; Takabe, R.; Du, W.; Baba, M.; Li, Y.; Toko, K.; Usami, N.; Suemasu, T. P-BaSi ${ }_{2} / \mathrm{n}-\mathrm{Si}$ Heterojunction Solar Cells with Conversion Efficiency Reaching 9.0\%. Appl. Phys. Lett. 2016, 108, 152101.

(22) Pokhrel, A.; Samad, L.; Meng, F.; Jin, S. Synthesis and Characterization of Barium Silicide $\left(\mathrm{BaSi}_{2}\right)$ Nanowire Arrays for Potential Solar Applications. Nanoscale 2015, 7, 17450-17456.

(23) Latiff, N. A. A.; Yoneyama, T.; Shibutami, T.; Matsumaru, K.; Toko, K.; Suemasu, T. Fabrication and Characterization of Polycrystalline $\mathrm{BaSi}_{2}$ by RF Sputtering. Phys. Status Solidi C 2013, $10,1759-1761$.

(24) Yoneyama, T.; Okada, A.; Suzuno, M.; Shibutami, T.; Matsumaru, K.; Saito, N.; Yoshizawa, N.; Toko, K.; Suemasu, T. Formation of Polycrystalline $\mathrm{BaSi}_{2}$ Films by Radio-frequency Magnetron Sputtering for Thin-film Solar Cell Applications. Thin Solid Films 2013, 534, 116-119.

(25) Hara, K. O.; Yamanaka, J.; Arimoto, K.; Nakagawa, K.; Suemasu, T.; Usami, N. Structural and Electrical Characterizations of Crack-free $\mathrm{BaSi}_{2}$ Thin Films Fabricated by Thermal Evaporation. Thin Solid Films 2015, 595, 68-72.

(26) Nakagawa, Y.; Hara, K. O.; Suemasu, T.; Usami, N. Fabrication of Single-phase Polycrystalline $\mathrm{BaSi}_{2}$ Thin Films on Silicon Substrates by Vacuum Evaporation for Solar Cell Applications. Jpn. J. Appl. Phys. 2015, 54, 08KC03.

(27) Nakagawa, Y.; Hara, K. O.; Suemasu, T.; Usami, N. On the Mechanism of $\mathrm{BaSi}_{2}$ Thin Film Formation on Si Substrate by Vacuum Evaporation. Procedia Eng. 2016, 141, 23-26.

(28) Hara, K. O.; Trinh, C. T.; Arimoto, K.; Yamanaka, J.; Nakagawa, K.; Kurokawa, Y.; Suemasu, T.; Usami, N. Effects of Deposition Rate on the Structure and Electron Density of Evaporated $\mathrm{BaSi}_{2}$ films. J. Appl. Phys. 2016, 120, 045103.

(29) Yang, Z.; Hao, Z.; Xie, Q. Effects of Annealing Temperature on the Structure and Surface Feature of Basi $i_{2}$ Films Grown on Si (111) Substrates. Phys. Procedia 2011, 11, 118-121.

(30) Sasaki, A.; Kataoka, Y.; Aoki, K.; Saito, S.; Kobayashi, K.; Ito, T.; Kakushima, K.; Iwai, H. Power Generation Characteristics of Schottky-type Solar Cells Fabricated Using Barium Silicide. Jpn. J. Appl. Phys. 2015, 54, 031202.

(31) Saito, T.; Tsukada, D.; Matsumoto, Y.; Sasaki, R.; Takeishi, M.; Ootsuka, T.; Suemasu, T. Wet Chemical Etching and X-ray Photoelectron Spectroscopy Analysis of $\mathrm{BaSi}_{2}$ Epitaxial Films
Grown by Molecular Beam Epitaxy. Jpn. J. Appl. Phys. 2009, 48, 106507.

(32) Haynes, W. M. CRC Handbook of Chemistry and Physics; CRC press: 2014.

(33) Takabe, R.; Du, W.; Ito, K.; Takeuchi, H.; Toko, K.; Ueda, S.; Kimura, A.; Suemasu, T. Measurement of Valence-band Offset at Native Oxide/ $\mathrm{BaSi}_{2}$ Interfaces by Hard X-ray Photoelectron Spectroscopy. J. Appl. Phys. 2016, 119, 025306.

(34) Hara, K. O.; Usami, N.; Baba, M.; Toko, K.; Suemasu, T. Ntype Doping of $\mathrm{Basi}_{2}$ Epitaxial Films by Arsenic Ion Implantation through a Dose-dependent Carrier Generation Mechanism. Thin Solid Films 2014, 567, 105-108.

(35) Hara, K. O.; Trinh, C. T.; Kurokawa, Y.; Arimoto, K.; Yamanaka, J.; Nakagawa, K.; Usami, N. Fabrication of $\mathrm{BaSi}_{2}$ Thin Films Capped with Amorphous Si Using a Single Evaporation Source. Thin Solid Films 2017, 636, 546-551.

(36) Du, W.; Takabe, R.; Baba, M.; Takeuchi, H.; Hara, K.; Toko, K.; Usami, N.; Suemasu, T. Formation of $\mathrm{BaSi}_{2}$ Heterojunction Solar Cells Using Transparent $\mathrm{MoO}_{\mathrm{x}}$ Hole Transport Layers. Appl. Phys. Lett. 2015, 106, 122104.

(37) Takahashi, K.; Nakagawa, Y.; Hara, K. O.; Kurokawa, Y.; Usami, N. Investigation of P-type Emitter Layer Materials for Heterojunction Barium Disilicide Thin Film Solar Cells. Jpn. J. Appl. Phys. 2017, 56, 05DB04.

(38) Vismara, R.; Isabella, O.; Zeman, M. Back-contacted $\mathrm{BaSi}_{2}$ Solar Cells: An Optical Study. Opt. Express 2017, 25, A402-A408.

(39) Somer, M. Vibrational Spectra of the Cluster Anions $\left[\mathrm{E}_{4}\right]^{4-}$ in the Metallic Sodium and Barium Compounds $\mathrm{Na}_{4} \mathrm{E}_{4}$ and $\mathrm{Ba}_{2} \mathrm{E}_{4}(\mathrm{E}=$ Si, Ge). Z. Anorg. Allg. Chem. 2000, 626, 2478-2480.

(40) Terai, Y.; Yamaguchi, H.; Tsukamoto, H.; Murakoso, N.; Iinuma, M.; Suemasu, T. Polarized Raman Spectra of $\mathrm{BaSi}_{2}$ Epitaxial Film Grown by Molecular Beam Epitaxy. Jpn. J. Appl. Phys. 2017, 56, 05DD02.

(41) Suhara, T.; Murata, K.; Navabi, A.; Hara, K. O.; Nakagawa, Y.; Trinh, C. T.; Kurokawa, Y.; Suemasu, T.; Wang, K. L.; Usami, N. Postannealing Effects on Undoped $\mathrm{BaSi}_{2}$ Evaporated Films Grown on Si Substrates. Jpn. J. Appl. Phys. 2017, 56, 05 DB05.

(42) Zi, J.; Büscher, H.; Falter, C.; Ludwig, W.; Zhang, K.; Xie, X. Raman Shifts in Si Nanocrystals. Appl. Phys. Lett. 1996, 69, 200-202.

(43) Tsybeskov, L.; Hirschman, K. D.; Duttagupta, S. P.; Zacharias, M.; Fauchet, P. M.; McCaffrey, J. P.; Lockwood, D. J. Nanocrystallinesilicon Superlattice Produced by Controlled Recrystallization. Appl. Phys. Lett. 1998, 72, 43-45.

(44) Evers, J. Transformation of Three-connected Silicon in $\mathrm{BaSi}_{2} . J$. Solid State Chem. 1980, 32, 77-86.

(45) Imai, M.; Hirano, T.; Kikegawa, T.; Shimomura, O. In Situ Measurements of the Orthorhombic-to-trigonal Transition in $\mathrm{BaSi}_{2}$ under High-pressure and High-temperature Conditions. Phys. Rev. B: Condens. Matter Mater. Phys. 1997, 55, 132-135.

(46) Shi, J.; Cui, W.; Flores-Livas, J. A.; San-Miguel, A.; Botti, S.; Marques, M. A. Investigation of New Phases in the $\mathrm{Ba}-\mathrm{Si}$ Phase Diagram under High Pressure Using Ab Initio Structural Search. Phys. Chem. Chem. Phys. 2016, 18, 8108-8114.

(47) Yang, G.; Zhang, Y.; Procel, P.; Weeber, A.; Isabella, O.; Zeman, M. Poly-Si $(\mathrm{O})_{\mathrm{x}}$ Passivating Contacts for High-efficiency C-Si IBC Solar Cells. Energy Procedia 2017, 124, 392-399.

(48) Hara, K. O.; Yamamoto, C.; Yamanaka, J.; Arimoto, K.; Nakagawa, K.; Usami, N. Investigation on the Origin of Preferred Aaxis Orientation of $\mathrm{BaSi}_{2}$ films Deposited on $\mathrm{Si}(100)$ by Thermal Evaporation. Mater. Sci. Semicond. Process. 2017, 72, 93-98.

(49) Hara, K. O.; Trinh, C. T.; Kurokawa, Y.; Arimoto, K.; Yamanaka, J.; Nakagawa, K.; Usami, N. Post-annealing Effects on the Surface Structure and Carrier Lifetime of Evaporated $\mathrm{BaSi}_{2}$ films. Jpn. J. Appl. Phys. 2017, 56, 04CS07.

(50) Hara, K. O.; Usami, N.; Hoshi, Y.; Shiraki, Y.; Suzuno, M.; Toko, K.; Suemasu, T. Structural Study of $\mathrm{BF}_{2}$ Ion Implantation and Post annealing of $\mathrm{BaSi}_{2}$ Epitaxial Films. Jpn. J. Appl. Phys. 2011, 50, 121202. 
(51) Gordienko, S. Thermodynamic Properties of Silicides of Alkaline-earth Metals. Powder Metall. Met. Ceram. 1997, 36, 502-504.

(52) Balducci, G.; Brutti, S.; Ciccioli, A.; Trionfetti, G.; Palenzona, A.; Pani, M. Thermodynamic Properties of Barium Silicides from Vapor Pressure Measurements and Density Functional Calculations. Intermetallics 2008, 16, 1006-1012. 